\title{
THINKING ABOUT TERRITORIAL MODERNIZATION AND DIFFUSE URBANIZATION IN THE AMAZON
}

\author{
pensando a modernização do território e a urbanização difusa na Amazônia
}

Saint-Clair Cordeiro da Trindade Júnior *

\begin{abstract}
Resumo
O artigo analisa a modernização do território e a importância do fenômeno urbano para as mudanças recentes verificadas na região amazônica. Utilizando-se das noçoes de "cidades da floresta" e de "cidades na floresta", busca-se compreender a urbanização difusa em curso nesse contexto regional, considerando-se, para isso, alguns exemplos de formas e conteúdos urbanos voltados para o atendimento de demandas econômicas externas à região. Finalmente, sugere-se considerar a ideia de "cidades para a floresta" como possibilidade de se pensar políticas territoriais para a Amazônia, espaço no qual o meio ambiente e as práticas culturais compõem importantes elementos da particularidade regional.
\end{abstract}

Palavras-chave: Modernização; Território; Urbanização Difusa; Regionalização; Amazônia.

\begin{abstract}
The paper analyzes territorial modernization and the importance of the urban phenomenon for recent changes in the Amazon Region. Using the notions of "forest towns" and "towns in the forest", this paper intends to understand diffuse urbanization, which is in progress, in a regional context. With this focus, it considers examples of urban forms and attributes regarding provisions for external economic demands. Finally, it is suggested that consideration be given to the idea of "towns for the forest" as a possible basis for the formulation of territorial policies for the Amazon, where environmental attributes and cultural practices reflect important elements of the regional peculiarity.
\end{abstract}

Key words: Modernization; Territory; Diffuse Urbanization; Regionalization; Amazon.

\section{Resumen}

El artículo analiza la modernización del territorio y la importancia del fenómeno urbano para los cambios recientes verificados en la región amazónica. A partir de las nociones de "ciudades de la selva" y de "ciudades en la selva", se busca comprender la urbanización difusa en curso en dicho contexto regional, considerándose algunos ejemplos de formas y contenidos urbanos destinados al cumplimiento de demandas económicas externas a la región. Finalmente, se propone considerar la idea de "ciudades para la selva" como posibilidad de pensar políticas territoriales para Amazonia, espacio en el cual el medio ambiente y las prácticas culturales componen importantes elementos de la particularidad regional.

Palabras-clave: Modernización; Territorio; Urbanización Difusa; Regionalización; Amazonia.

(*) Lecturer, Doctor of the Federal University of Pará (Universidade Federal do Pará) - Av. Augusto Corrêa, n. 1, NAEA-Sala 216, Bairro Universitário, CEP: 66.075-900, Belém, (PA), Brasil. Tel: (+55 91) 3201-7231 - stclair@ufpa.br 


\section{INTRODUCTION}

Known in the past as a "green hell", suggestive of the idea of unhealthiness and accompanied by a vision of the region as a homogeneous and poorly differentiated space, today there is talk of an economic frontier and techno-ecology (BECKER, 2004) and "the Amazons" (PORTO-GONÇALVES, 2001) when referring to the spatial and territorial configurations that exist in the Amazonian regional space. On the whole, such settings articulate the logic of diffuse urbanization, which can also be found throughout Brazil.

It is in this sense that expressions such as "urban frontier" (BECKER, 1990), "urbanized forest" (BECKER, 1995), "urbanization in the jungle" (OLIVEIRA, 2000), "complex and disarticulated urbanization" (BROWDER; GODFREY, 2006) and "extensive urbanization" (MONTE-MOR, 2014) have been used to name the diffuse urbanization taking place in the Amazon, which reconfigures its space internally, expanding new processes hitherto foreign to the region and at the same time fragmenting its immense territory into different sub-regions.

In view of this, the intention of the present analysis is to discuss this form of urbanization, recognizing and relating it to more general processes that seem strange to the region as they do not making its geographical and sociocultural attributes more potent, and that on the other hand, increasingly tend to insert it into economic and political models of territorial planning that are normally conceived outside the regional space and serve interests remote from local social demands

Initially, the understanding of diffused urbanization is discussed, differentiating it from the dispersed urban fabric, which in turn is associated with intra-urban and intra-metropolitan spaces. Next, particular attention is paid to the new nexuses of modernization of the territory in the Amazon, highlighting the different ways of interpreting it, along with some expressions of the contemporary urban phenomenon at different levels and types of cities. In this context, there is a discussion of the diffusion of "cities in the forest" to substitute the "forest cities", finalizing with a reflection on the idea of "cities for the forest"; as this is a possibility when considering territorial policies for the Amazon starting from its geographical and cultural potential and peculiarities.

\section{URBAN DISPERSION AND DIFFUSE URBANIZATION: APPROXIMATIONS AROUND THE THEME}

In the process of contemporary modernization it has been common to associate important territorial transformations with a given urban lifestyle. If we consider space as a product, condition and means of social relationships (LEFEBVRE, 1974), it is not hard to understand the reason for this association, which occurs on both a city and a regional scale; hence the need to establish the differentiation and correlation between diffuse urbanization and urban dispersion, both very common in today's society.

In the latter case, we are referring mainly to the dispersion of the urban area/sprawl that occurs in its most expressive form nowadays in metropolitan spaces but has also revealed itself in other non-metropolitan urban forms. This is an expression of the urbanization that occurs in intra-urban contexts and that, on the whole, takes on a metropolitan reach.

As a result of the process of modernization of society and different capital accumulation strategies, new spatial forms develop not only through higher density and verticalization of urban land, but also through movements of horizontal expansion and dispersal of the increasingly dense fabric, as we have systematized elsewhere (TRINDADE JR., 1998). Such processes are materialized by the complexity of uses and forms of appropriation of space, whose fractions, which define a spatial unit, are not necessarily continuous and contiguous from the locational point of view. They are in fact a functional unit with continuous, not intermittent, flows since concentration does not necessarily imply a single urban area, but mainly the intensity of flows between relatively close spaces, as shown by Lencioni (2015) when addressing city-regions and macro-metropolises. 
In this sense, Soja $(2013,2014)$ discussed multiple scales of regional urbanization, in which there is a generalized process of diffusion of the urban phenomenon to the point of estimating that there are approximately five hundred mega-urban areas with more than one million inhabitants worldwide. According to Soja, these regions extend in recognized dynamic spaces from an economic point of view, as in the case of the Asian Tigers and Silicon Valley, but also appear far from these epicenters of the world economy, such as in the Siberian tundra and the Amazon rainforest (SOJA, 2013).

Thus dispersion and concentration are presented as true dialectical pairs of socio-spatial processes involving the internal restructuring of cities. In this case, the urban conformation presupposes a certain primacy of central areas, as well as new centralities in the dynamics of the appropriation of space. For capital, the existence of the dispersed form and the decentralized metropolis is the key factor for its expanded reproduction; hence the new role of the new centralities in the current stage of capitalist accumulation.

Although dispersion is important for understanding the capitalist reproduction process at a metropolitan level, diffuse urbanization is, in turn, the projection of this process on a wider regional and territorial level, going beyond the principle more concentrated conurbations and reaching other spaces hitherto unmarked by the installation of modern urban life.

Associating this process to his thesis on urban society and complete urbanization, Lefebvre $(1970,2014 a)$ demonstrated that this is a real and virtual tendency of the modern contemporary world:

Nous partirons d'une hypothèse: l'urbanization complète de la société... Cette hypothèse implique une définition. Nous appellerons "societé urbaine" la société qui résulte de l'urbanisation complète, aujourd'hui virtuelle, demainré elle. (...) Ici, nous réserverons le terme "société urbaine" à la société qui naît de l'industrialisation. Ces mots désignent donc la societé constitués par CE processus lui-mêm e dominant et résorbant la production agricole (LEFEBVRE, 1970, p. 7-8).

Even if the metropolis is the space par excellence for the materialization of urban society, this process, referring to the urban way of life that is born of industrialization and its values, is not only confined to that spatial form. It also becomes relevant and manifests itself as attributes in non-metropolitan urban forms, as well as in other areas initially thought to be non-urban; hence the idea of the "planetarization of the urban" also mentioned by Lefebvre (2014b).

The dimension that the urbanization of society currently holds and the role that cities take on in the context of the reproduction of urban living, even led Lencioni (2003) to speak of a process of the metropolization of spaces, which seems to be an expression of the urbanization of society that Lefebvre (1970) dealt with. This is because they are metropolitanized spaces, in the sense that they assimilate metropolitan attributes without necessarily being integrated into the conventional geographical perimeters of metropolises.

In the case of Brazil, Santos (1993) analyses this phenomenon by referring to the idea of the urbanization of territory. For this author, from a process of growth in urban populations due to the modernization of Brazilian society that gradually began to live in cities, especially large ones, a form of urbanization hitherto mostly confined to major urban centers was observed in which the nexuses of modernization began to spread throughout the country.

Together with this diffusion, almost simultaneously throughout the country, the aforementioned author drew attention to the "metropolitan dissolution". This phenomenon, characterized by the presence of the metropolis in every part of the territory, has increasingly made locations adapt to the hegemonic mechanisms of economic reproduction, given the omnipresence of their attributes at the same moment of the current historical period.

Thus, on reaching new population levels and gaining new urban attributes the intermediate-sized urban centers, as well as small towns that formerly had strong rural attributes, respond more intensely to the territory's need to modernize and new economic demands, which have urban characteristics. The effect of this process can be seen in small towns. They are transformed as never 
before and are no longer only "cities of notables" associated with the interests of traditional local powers; they gradually become "economic cities", since they start to follow and meet the demands of the modern activities that are installed in the area (SANTOS, 1993).

Diffuse urbanization was also considered by Simoni Santos (2013), who interprets the process of reproduction of urban space as a condition, means and product of the accumulation of capital in the current historical moment. For this author, the process of metropolitan concentration in Brazil has been going through profound transformations since the 1990s. He argued that urbanization extends in time because it can extend in space and it also expands in the Brazilian territory, which profitably has absorbed the surpluses often generated in the Brazilian economy.

This diffuse and expanded form of urbanization in the whole Brazilian territory, including Amazonian space, was only possible with the endorsement of a developmentalist State that created the conditions for this expansion at a national level. Today, this expansion is in line with a new period of the geographical centralization of capital that is also expressed in the metropolises, recreating the old centralities, producing others, and as a result, promoting the geographical intensification of capital that in the era of globalized finance becomes the center of accumulation strategies (SIMONI SANTOS, 2013).

We mean by this that urban dispersion at a metropolitan level, along with diffuse urbanization at a regional and national level, are not part of different, opposing processes. On the contrary, they are part of a single movement of capital accumulation in the territory within which the urban becomes the condition for this same accumulation process to occur; in its phenomenal form, on the one hand it emerges as concentration in certain parts of the territory, and on the other, as diffusion in pulverized spaces throughout the country.

\section{DIFFUSE URBANIZATION AND THE NEW NEXUSES IN THE MODERNIZATION OF THE AMAZON}

In the Amazon, diffuse urbanization has been studied by various authors. For example, Becker (1990), initially more concerned with the geopolitics that gave meaning to the occupation of the east of the Amazon, where the action of the State was determinant, made a relevant contribution when speaking of the importance of the city and the urban in understanding the new socio-spatial attributes responsible for defining the recent territorial logic of Amazonian space.

Having this concern, she came to refer to this region as an "urbanized forest" (BECKER, 1995). With an argument centered on a clear theoretical proposition she defined the "urban frontier" as part of the economic frontier (BECKER, 1990), as one configured by spaces of urban population growth with evidence of the expansion of the physical dimensions of the cities and a proliferation of new population nuclei, but equally, the diffusion of urban values and new and renewed forms of the reproduction of capital and social control.

Becker considered that, within this explanatory scheme, the expansion of the economic frontier occurred initially in an urban context, since the migratory flow did not have a predominantly rural destination. In this dynamic the urban, as socio-spatial characteristics, became a strategy for the occupation of the territory under a particular logic of economic and social reproduction, resulting in a complex and dynamic organization of space. The urbanization process from the second half of the twentieth century was related by the author to the intense mobility of the workforce, explained both by the expropriation and difficulty of access to land, but also by migration, regarded as a condition of the settlement and formation of the workforce for the new relations that unfolded at the regional level (BECKER, 1990).

The precarious nature of the labor force - temporary, mobile and versatile - was also considered as part of this analysis and justified a form of exploitation that did not necessarily presuppose automatic proletarianization, unlike other classical processes in the interior, in which expropriation 
and expulsion from the land led linearly to salaried work in an urban context, linked to the activities of cities (BECKER, 1990).

Thus, urbanization on the frontier is not associated with the straightforward urbanization of the population, as has been observed in several realities studied in the eastern and southern parts of the region. Furthermore, the urban was seen as a logistical base for a mobile and versatile workforce and urban policies, particularly those defined at the federal level, which establish conditions for intra-regional circulation and the resocialization of the migrant in the space of the destination (BECKER, 1990).

This is how the workforce's mobility became an important element to explain the meaning of the so-called "urban frontier" and the very existence of the frontier, initially of resources (BECKER, 1990) and more recently techno-ecological (BECKER, 1997). For capital, urban space meant a reference base by means of which manpower was recruited and distributed and a more rational use of the workforce was established. Given their versatility and flexibility the time required to train workers was also minimized, increasing consumption needs. If these advantages favored the capitalist reproduction process, for workers they meant greater instability and exploitation, as well as difficulties in trade union and political organization, but were also a survival strategy of the peasant family (BECKER, 1990).

Even if nowadays the urbanization process is not the same as the one during the first moments of the formation of the frontier, it has not stopped being important in the definition of what she called the technological frontier. For Becker (2004), today cities: a) represent millions of consumers; b) are the headquarters of public and private political institutions; c) offer alternatives for employment and income, preventing migration to the forest; d) are the potential base for local processing of forest products; e) are distribution centers of services for the populations of the Conservation Units (CUs) and Indigenous Lands (TIs); f) are potential centers for agrarian reform settlements in areas to be recovered; g) have a logistical role in connecting different modes of transportation and communication networks; and h) act as relays for the regional unit.

Browder and Godfrey (2006), in turn, in studies focused on urbanization due to agrarian colonization, as seen in the southern and eastern Amazon, defended a conceptual pluralism in the discussion of the Amazon region, because of the complexity that its urbanization process reveals.

Questioning the precepts of what they call globalism, they argued that urbanization in the region is the result of a myriad of hybrid micro-social formations, because of the diversity of the human settlements and their systems and, consequently, with marked differences between them. These differences stem from local history, social composition, institutional affiliations and regional and sub-regional economic functions (Browder; GODFREY, 2006).

The authors suggested a theory called "disarticulated urbanization" for the region, based on the fact that it is a heterogeneous social space consisting of different ethnic and social groups, incapable of being interpreted by a single concept or master principle. The polymorphic and irregular systems of cities have functions that interact differently with the world economy, as agricultural expansion and industrial development do not occur in a generalized manner but are located sporadically, although the growth of the urban population is manifest throughout the region (Browder; GODFREY, 2006).

The same authors admitted the strong integration of some productive areas with global economic forces but considered that the region as a whole is not subject to the global economic system, due to the sectoral disarticulation of economic development and the lack of an effective and widespread system of market forces and labor relationships of production. Likewise, being a geopolitical creation, the "urban frontier" is politically disarticulated from central government, which does not represent a unifying force of civil society. Its variable and ambiguous role has contributed to the growing socio-economic differentiation in the region, in which context the rural and urban dichotomy does not apply (Browder; GODFREY, 2006).

Oliveira (2000), in turn, did not speak precisely of the "urbanized forest", like Becker, but suggests the existence of an ongoing process that could be called "urbanization in the jungle", refer- 
ring mainly to the western Amazon. For this geographer, urban in the Amazon frontier differs from what has been observed by other authors in other parts of Brazil, although they have in common the fact that it is a frontier that is born urban:

here the urban imposes itself as the initial base of a process. The city emerges in the beginning and not as a result of the process, being associated with the expansion of new activities and serving as their support, on the economic level and especially on the institutional one. Unlike the pioneering front in the north of Paraná, there are no cities close to one another. In the Amazon, the frontier is born urban, not as a city domain in the landscape, but as the predominance of the urban as lifestyle that is established and tends to predominate (OLIVEIRA, 2000, p. 186-187).

However, the aforementioned author does not conceive of the Amazon as a simple frontier of resources, as this idea is associated with "demographic emptiness", which was a forward strategy of large capitalist enterprise, notably through the Second National Development Plan for 1975-79. Neither does he connect the process of expansion to a necessary improvement in the quality of life, but to other forms of life that enter the region:

the expansion of the frontier constitutes a contradictory, multifaceted movement, which confers on it a simultaneously destructive and constructive dimension. The former appears in the explanation of the ways that space is appropriated and the social inequalities, and the latter in the resistance that creates the conditions to establish new ways of life that do not mean a return to the prior existence, but another life (OLIVEIRA, 2000, p. 188).

In the diffusion of the new urbanization process, specifically in the western Amazon, the abovementioned author points out that this process should not be dealt with just from the economic or demographic point of view, or by always placing them in the foreground. He warned of the need to pay attention to the resistances facing them, as well as how to attract the transformations and the dimensions of the living space in order to allow multiple social, political and economic contradictions that manifest themselves in the regional space. He highlighted some elements to be considered in this sense: a) the strong presence of the indigenous culture, especially in older cities; b) the relative geographic isolation, which does not prevent cities from suffering the influence of a broader cultural context, tending to weaken local culture; c) the ever recurring reference to certain periods of pursuit of wealth, whether from the riverbanks or from the roadside; d) the fact that they reflect the local conditions and the conflicts inherent to them, which are not characterized merely by their economic nature; e) the properties of their forms of organization and structure, which go beyond their specific dimensions, setting elements and styles that are defined beyond their spatial divisions (OLIVEIRA, 2000).

Given the existence of these multiple elements, Oliveira (2000) also drew attention to the risk of considering these same cities as part of a more general culture and always taking as references the dimensions and complexities of the most dynamic centers rather than starting from a recognition of the cities themselves.

Another author who reflects on diffuse urbanization in Brazil and the Amazon is Monte-Mór (2014a, 2014b). On interpreting the meaning of contemporary urbanization, he recognized in the Amazon what he called "extensive urbanization" or "extended urbanization", relating it to the different patterns of urban settlement in Brazil. This interpretation is based on the Lefebvrian assumptions about urban society, seen as virtuality and a concrete form of the extension of the urban fabric in multiple dimensions and directions, including unbuilt space, leading him to admit the presence of urban attributes beyond the restricted areas of cities.

Like the author who inspired him, he understood "extensive urbanization" as the actual projection of urban society. It is thus a set of manifestations of the urban that, to cite Lefebvre (1970), lead to the predominance of the city over the countryside, materialized in various ways, such as 
the second home, the highway and the supermarket. All these elements make up the urban fabric, which can be more or less dense, thick and active to the point that new spatial forms, like the agricultural village, can lead to the possibility of the disappearance of others, such as the old Indian settlements (LEFEBVRE, 1970).

Monte-Mór (2004) argues that in Brazil, urbanization has extended itself over virtually all the national territory, integrating and submitting the multiple regional spaces to the urban-industrial centrality that projected itself from the main Brazilian conurbations, with an emphasis on the metropolis of São Paulo:

I have called this urbanization that occurred beyond the cities and urbanized areas along with the general conditions of industrial production extensive urbanization. Extensive urbanization can be defined as the socio-spatial form that expands the urban-industrial conditions of production (and reproduction) over the regional space, articulating the urban and the rural in a single and (virtually) integrated urban form also carrying with it the specifics of polis and civitas: urban praxis, politics and citizenship (MONTEMÓR 2004: 115, emphasis added.).

The author emphasized that this form of urbanization, which extends to old and new regions and territories, results in diverse and distinct combinations of processes and socio-spatial forms, which in turn do not only represent local manifestations of dynamic and hegemonic elements of urban-industrial centers. They also express particularities of multiple traditional practices that are (re)created by immediate needs, which are fruits of multi-temporal heterogeneities merging within the social production of space (MONTE-MÓR, 2004).

The configuration of the urban networks that materialize this "extensive urbanization" in the Legal Amazon may appear similar to the other regions in the country, with the emergence of medium-sized cities, ${ }^{1}$ the multiplication of small urban areas etc. However, they are characterized by diverse aspects, with regional and local urban centers that have distinct demographic, socioeconomic and spatial particularities and dynamics (SATHELER; MONTE-MÓR; CARVALHO, 2009).

Like the authors referred to above, Monte-Mór draws attention to the complex nature of Amazonian urbanization and at the same time emphasizes the need to avoid considering this process, which has increasingly contributed to internally differentiate the Amazonian space, as homogeneous. Some examples may help to visualize this issue better, taking into account the different forms and urban characteristics existing in the region.

\section{“CITIES IN THE FOREST": EXPRESSIONS OF DIFFUSE URBANIZATION}

From the 1960s onwards a new restructuring of the Amazonian space took place, this time with a fundamental role played by the state and big business. Through infrastructure and tax and credit incentives a phase of rapid occupation of the territory was inaugurated, with the presence of entrepreneurs, speculators, and migrants, who mediated by intentional State actions defined a new order imposed on the territory.

In this process development strategies tend to be based on at least three main types of land use planning, which despite the continuity between them, suggest very different geometries: the points (poles of growth), the lines (integration axes ) and the zones (social- environmental fabric).

In these strategies, cities play important roles in the face of regional development policies as part of an "intentional" or "spontaneous" logic of territorial planning (MACHADO, 2000) and together they are presuppositions for the new regional configuration. In this new context, some expressions of urbanization merit consideration given their respective importance for the internal differentiation of Amazonian space on different scales, as suggested by Becker (2004).

Following the reasoning of this author, on a macro-regional scale, for example, the diffuse urbanization process arising from territorial policies defines at least four very specific sub-regions: the central-eastern Amazon directly controlled by Belém (PA); the western Amazon controlled by 
Manaus (AM); the eastern Amazon controlled by São Luís (MA); and the southern Amazon under the influence of Cuiabá (MT).

Still inserted into the idea of region-program, constituted by means of the Legal Amazon, especially since the creation of the Superintendence for Amazon Development (SUDAM) in 1966, each macro-region has been configured in relation to the most significant urban center in the regional urban network. Even taking into account that the metropolization phenomenon has similar processes in these four macro-regions, in the case of the Amazon the characteristics the aforementioned cities maintain vis-à-vis their sub-regions are remarkable.

The character of Belém, the oldest of the four, resulted from the repercussions of the first expansion fronts arising from the post-1960 regional integration; in Manaus it is the result of the creation of the Free Trade Zone in the 1960s, but it began to be defined as a metropolis in the following decade; that of São Luís is directly associated with the Carajás Project and the latest expansion frontiers from the 1980s and 1990s; and Cuiabá is a conurbation that is still being formed but that has influence on a sub-region where rural modernization has shown significant dynamism in recent decades, as it serves important national and global markets.

It is in this context of internal regional differentiation that a diffuse urbanization process occurs equally in various parts of the regional space and inside these macro-regions, more or less affected by the new means of circulation and by several economic fronts that renew themselves over time.

The strong presence of the State composed the strategy of the regionalization model based in the polarized regions, either by creating infrastructure; or by setting up planning and funding bodies; or additionally by tax /credit incentives /subsidies to big rural property and capital flows. The regionalization designed from these poles was accompanied by the arrival of agents with different backgrounds and in different migratory waves. They were responsible for the emergence of urban centers or the growth and expansion of existing small villages, which culminated later in the reconfiguration of the municipal fabric given the presence of a new or renewed local economic and political power, which defined territorialities whose epicenters became the political headquarters of the new and old towns.

The spread of modern urban values in and from these cities led to our suggestion, made elsewhere (TRINDADE JR., 2010, 2013), for the recognition of a process in which the "forest cities", the most common in the region until the first half of the twentieth century, are losing importance to the "cities in the forest", which have gained relevance with the policies of regional integration. Strongly connected with the dynamics of nature and local ecosystems the former, despite their relationship with external spaces, have always established intense and organic relationships with their immediate surroundings and with other relatively close locations (villages, towns, riverside communities etc.).

The cities that emerge from the second half of the twentieth century and the new urban values that replace those already established for some time, tend today, much more than in the past, to articulate themselves mainly to demands external to the region, denying the forest's potential, from the perspective of its ecological attributes and in relation to the cultural values rooted in it; viewing it primarily as a source of resources for economic exploitation (wood, minerals, fragrances, animal and plant species, tourism etc.)

Among the urban centers that comprise these changes are those stimulated to emerge or grow from the various models for territorial planning, such as the so-called "rural urbanization" - where urban and rural were combined by new spatial forms (agricultural villages, agro-polis and Rurópolis) - under State control (National Institute of Colonization and Agrarian Reform - INCRA) or private companies (land colonization companies), along the highways and associated with several economic projects dispersed throughout the region. Some of them have become small towns, but not necessarily local cities, given their meager ability to meet the social demands of their immediate surroundings. 
However, one of the best expressions of diffuse urbanization is associated with the concept of regionalization supported on the growth poles designed for the Amazon in order to facilitate large corporate interests. Initially conceived as closed cities, cities established for these purposes were linked to mining projects and infrastructure, becoming models of an extraverted urbanism with little local interaction, although the discourse constructed about some of these cities portrayed them as open or semi-open, as well as claiming to meet the demands of the surrounding area.

In any case, regardless of their differences in this sense they indicate a new standard of development and urban planning for the region by harboring skilled labor, and also by exerting a strong pressure on the forest environment in two ways. The first due to the rationale behind the emergence of this type of city, which is related to various forms of exploitation of resources linked to global circuits, such as the exploitation of iron ore, bauxite and water for the production of electricity, all of which usually have strong local and regional impacts. The second is because of the symbolic and cultural value, which refers to the idea of estrangement / displacement of these cities and their contents in relation to local history and pre-existing everyday experiences.

Currently, the neo-developmentalist assumptions that still underpin the presence of large resource exploitation projects in the region redefine the importance of integrating this kind of city into the Amazon region. Even those already established tend to have their management passed on to local government and not to the companies associated with them, overburdening the municipal sphere's ability to deal with the local impacts and repercussion generated by these developments.

The recent experiences of diffuse urbanization associated with big business do not even conceive of implementing "company cities." Instead there is the discourse about "companies of the city", through which the pre-existing urban centers undertake to house the new project to be deployed, moving towards the idea of full insertion of the corporations in the local spaces.

The expectation of economic growth, which usually accompanies the implementation of new projects, makes the local population and government of the cities where they settle adopt these businesses as their own; such is their importance and the role they play in the local sphere of consciousness. The expectation of economic growth and local development to be provided by the presence of these companies is always accompanied by discourse about the modernization of the territory, as noted in relation to copper exploration in Canãa dos Carajás in southeast Pará by Vale S.A.; regarding the exploration of bauxite in the Municipality of Juruti in the Lower Amazon by Alcoa; and the Onça Puma Project (Vale S.A.), which mines for nickel in the south of Pará, and that has "host communities" in the cities of Ourilândia do Norte and Tucumã.

The economic and territorial modernization often masks the social and environmental costs and onus caused by the undertakings, through their activities and the personnel directly or indirectly linked to them. At the most, the infrastructure installed by the company itself has a provisional character, a type of top quality campsite that can be taken down after the enterprise's activities begin, as can be observed around the works of the Belo Monte Hydroelectric Plant, more specifically in the municipalities of Vitória do Xingu and Altamira in the southwest of Pará, which is the responsibility of Norte Energia S.A..

So, unlike preceding decades, there are new forms of urban diffusion in the region, which differ from those inspired by the interventionist development of the first decades of regional integration. Authors like Ablas (2003), Galvão and Brandão (2003), Mello (2006) and Leitão (2009) drew attention to the concept of a new territorial organization designed for Brazil from the 1990s, associated with the axes of integration and development and leaving behind the idea of poles, ushering in a new form of regional development policy.

The neoliberal options have an inbuilt strategic concept of planning. Through this there is a systematic optimization of the exploitation of opportunities, with multiplier effects and consortial and partnership actions between public and private initiatives, in which the state acts as broker and investment flag, aiming at the competitive insertion of Brazil and, consequently, the Amazon in the global market. 
The new planning regions take on a linear configuration, and the idea of polarization stops being occasional to spread through the existing or potential axes (nodes, networks and paths) to establish connections between local and sub-regional spaces and the global market. From these new milestones, regional integration is powered by the internalization of development and "export corridors". The conception is of a new logistical and infrastructural "regional armature" where transport is a crucial element, articulated to other networks (telecommunications, electricity and cities).

It is in this context that the urban network takes on a less hierarchical rigidity, defining short-circuits and conferring importance on the new regional urban centers, which work as real "nodes" for flows, based on various products, such as those stemming from biodiversity and ecotourism, but especially those related to agribusiness and mining, as can be observed, respectively, in the soya circuit, which includes the city of Santarem, and the iron circuit, which includes the city of Marabá, both in the state of Pará.

It is largely the intermediate urban centers of the urban network that are raised to the condition of medium-sized cities. With important sub-regional roles these cities are also good expressions of the diffuse urbanization that is present in the region today because of their urban attributes. These are cities that play a central logistical role, in the sense that they establish connections to different modes of transport and communication networks, and whose infrastructure, commerce and services are intended to meet the corporative demands linked to commodities with a wide acceptance in global markets and, therefore, they also exert pressure on the forest environment.

Examples of new urban content in these cities include a large number of car dealerships, a proliferation of bank branches, the spread of shops and services focused on agribusiness, an increase in national and international franchises, and the insertion of large consumption-based structures that are a modern part of the urban economy, such as department stores and shopping malls.

However, it is not only economic attributes that define the centrality of these nodal points in the territory. Even granting the importance of the economic dimension, largely associated with commercial activities and modern services, they have another form of centrality that distinguishes them at the regional level. We are referring to political centrality, characterized by the presence of official institutions and organizations, and the decision-making state and federal agencies, and the fact that they host the major political parties, associations, trade associations, trade unions and diverse social groups.

On the other hand, as part of this political dimension that reinforces urban centrality there are important movements that become showcases for political interests and from which projections of new territorialities are established at a sub-regional level. Some examples are the proposals for the creation of new states in the federation, such as Carajás (south/southeast of Pará), with its political headquarters in Marabá, and Tapajós (western Pará) with its political headquarters in Santarém.

Thus, faced with the most recent neodevelopmentalist strategies, the sub-regional urban centers affirm themselves as important targets for the territorial policies coming from a federal and state level, as points of investments and diverse services responsible for increasing and broadcasting a sphere of urban values throughout the Amazon, previously seen only in metropolitan environments of the same region.

\section{FINAL CONSIDERATIONS}

Added to the territorial planning model of poles and corridors / integration axes, there is a growing association with a new form of territorial planning that is based on zonal geometry and a discourse of sustainable development.

This is a type of overlay of intentional practices conceived from territorial policies of regional development, as analyzed by Vale (2015) for the Amazon in the state of Maranhão. However, we wonder to what extent new spatial geometric points anchored in extraverted models can generate results that have a lighter impact and are socially more just? 
In reality, we must agree with Becker (1997), who in showing the current coexistence in the region between a frontier economy and a techno-ecological development vector, suggests the existence of not just one, but a plurality of discourses constructed on the premises of sustainable development. In the same vein, agents present themselves as holders of these premises, from environmentalist and preservationist movements defending nature to actors from more alternative development projects and even economic agents who, supported on a type of ecological geopolitics, endorse the interests of large corporations and increased capital reproduction.

In this way, different development strategies coexist, with the same label that apparently unites them, in view of the need for further consultations and political arrangements which support the role of the State as mediator / orchestrator of different interfaces between the public and private; in the integration of projects / programs and trans-scale partnerships, which include both government institutions and civil society; as well as in the rhetoric and practice around participation and the shared management of the territory (BECKER, 1997; MELLO, 2006).

From the point of view of territorial planning the intention today, more than in the past, is to configure a zonal geometry that does not rule out the complex techno-political fabric inherited from the past, but that includes techno-ecological and environmental concepts of development in the "regional armature", exemplified by economic-ecological zoning based on the recognition, among others, of indigenous lands, protected areas, extractive reserves (BECKER, 1997) and more recently, citizenship territories, as shown Souza (2014).

Diverse sub-regions that also have diverse potentials are recognized to the point of being considered subsidies for territorial and environmental management policies, as proposed by Becker (2004). In this configuration, the cities are treated as nodal and logistical points because, among other reasons, they exert a low pressure on the forest environment and they are potential centers to support local and sub-regional surrounding areas, both in degraded areas to be recovered and in areas to be conserved and preserved.

In this way, and having in view the thesis of urban society and the trend of diffuse urbanization also present in the Amazon region, as shown in the discussion undertaken herein, we seek to question the pertinence of thinking of "cities for the forest" as a possibility when faced with the contradictory movement that arises between the "forest cities" - which are dynamic and not simply frozen spaces in time - and the increasingly striking presence of "cities in the forest" - given the role played not only by new planned or spontaneous nuclei, but also by new urban characteristics that spread in the regional space indifferent to the forest's ecological and cultural potential, regarded as a socially produced space.

Going beyond the concept of "city in the forest", which dominates the territorial and urban policies in the Amazon and surpassing an essentialist interpretation of "forest cities", we must, therefore, pay attention to the experiences of the urban lives present in the region that still dynamize important parts of the internal order of cities, in order to signal another kind of urbanism, quite different from what has been designed by diffuse urbanization until now. There are socio-spatial experiences and practices, usually rendered invisible by official policies, which deserve to be examined and recognized. This is because the daily life present in many Amazonian cities offers possibilities and potentialities not just to assess the nature of the ongoing urbanization, but also to think about "cities for the forest", less formatted to external standards and less committed to a single model of life and urban values.

This reading helps us to see the Amazon as a non-homogeneous region as well as to think about urban diversity as another dimension that adds to those of biodiversity and social diversity, both considered for longer in the territorial policies directed towards the region. This is an urban diversity revealed empirically not only by various types of city and the existence of multiple types of urbanization, normally arising from processes originating outside the region, but also by complex forms of spaces that indicate the hybridization of relationships; the result of contacts and interactions 
in the face of movements of a different nature coming from outside and that blend with those from within, revealing residual spaces and resistances.

\section{NOTES}

(1) Regarding the definition of medium-sized cities see the work of Sposito (2001a) from which our reflections take conceptual support, considering them as urban areas whose nature and profile are not restricted to a demographic amount and whose locations are not confined to the perimeters of conurbations. Notably, they define themselves by the importance and the strategic geographic position in the regional scenario in which they operate and are characterized mainly by the relative density of points and flows that meet not only local demands but are the result of combinations of influences and determinations from different scales, including the global level. We speak thus of centrality, linking it to the importance of flows (SPOSITO, 2001b), which often intensify as a result of a few available nodes. As we have argued in the case of the Amazon region, it has not necessarily been the density of nodes in these cities that is the element responsible for giving them importance in recent years. Centrality, thus understood, results from the convergence of flows and is defined by the centripetal character they exercise toward a particular point of the urban network, the "node" of the movement of goods, people, information and capital, due to a given availability of infrastructure and a relative technical density of economic, social and political activities that tend to focus at that point, (TRINDADE JR .; RIBEIRO, 2009).

\section{ACKNOWLEDGEMENTS}

This article systemizes discussions from previous research projects: "The urban and the regional in the geographical understanding of Amazonian space: readings and approaches in perspective", postdoctoral internship member at the University of São Paulo (USP), in 2015-2016, and "A geographical look in perspective: the Amazon in the approach to space as a social entity" under our coordination and accountability, and funded by the National Council for Scientific and Technological Development (CNPq), an entity of the Brazilian government dedicated to scientific and technological development.

\section{BIBLIOGRAPHIC REFERENCE}

ABLAS, L. A. O "Estudo dos Eixos" como instrumento de planejamento regional. In: GONÇALVES, M. F.; Brandão, C. A.; Galvão. Antônio Carlos Filgueira (Orgs.). Regiões e cidades, cidades nas regiões: o desafio urbano-regional. São Paulo: Editora Unesp, 2003. p. 171-186.

BECKER, B. K. Amazônia. São Paulo: Ática, 1990.

BECKER, B. K. Undoing myths: the Amazon - an urbanized forest. In: CLÜSENER-GODT, M.; SACHS, I. (Orgs.). Brazilian perspectives on sustainable development for the Amazon region. Paris: UNESCO, 1995. v. 15. p. 53-89.

BECKER, B. K. Novos rumos da política regional: por um desenvolvimento sustentável da fronteira amazônica. In: BECKER, B.; MIRANDA, M. (Orgs.). Geografia política do desenvolvimento sustentável. Rio de Janeiro: Editora da UFRJ, 1997. p. 421-443.

BECKER, B. K. Amazônia: geopolítica na virada do III milênio. Rio de Janeiro: Garamond, 2004.

BROWDER, J.; GODFREY, B. Cidades da floresta: urbanização, desenvolvimento e globalização na Amazônia brasileira. Manaus: EDUA, 2006. 384 p.

GALVÃO, A. C.; BRANDÃO, C. A. Fundamentos, motivações e limitações da proposta governamental dos Eixos Nacionais de Desenvolvimento e Integração. In: GONÇALVES, M. F.; BRANDÃO, C. A.; GALVÃO, A. C. (Orgs.). Regiões e cidades, cidades nas regiões: o desafio urbano-regional. São Paulo: Editora da UNESP, 2003. p. 187-205.

LEFEBVRE, H. La revolutión urbaine. Paris: Gallimard, 1970. 256 p.

LEFEBVRE, H. La productión de l'espace. Paris: Anthropos, 1974. 485 p.

LEFEBVRE, H. From the city to urban society. In: BRENNER, N. (Ed.). Implosions/explosions: towards a study of planetary urbanization. Berlin: Jovis, 2014a. p. 36-51.

LEFEBVRE, H. Dissolving city, planetary methamorphosis. In: BRENNER, N. (Ed.). Implosions/explo- 
sions: towards a study of planetary urbanization. Berlin: Jovis, 2014b. p. 566-570.

LEITÃ̃, K. O. A dimensão territorial do Programa de Aceleração do Crescimento: um estudo sobre o PAC no Estado do Pará e o lugar que ele reserva à Amazônia no desenvolvimento do país. 2009. 285 f. Tese (Doutorado em Arquitetura e Urbanismo) - Faculdade de Arquitetura e Urbanismo, Universidade de São Paulo, São Paulo, 2009.

LENCIONI, S. Uma nova determinação do urbano: o desenvolvimento do processo de metropolização do espaço. In: LEMOS, A. I. G.; CARLOS, A. F. A. (Org.). Dilemas urbanos: novas abordagens sobre a cidade. São Paulo: Contexto, 2003. p. 35-44.

LENCIONI, S. Metropolização do espaço e a constituição de megarregiões. São Paulo: USP, 2015. (mimeo.).

MACHADO, L. O. Urbanization et marché du travail en Amazonie brésilienne. In: DIAS, L. C.; RAUD. C. (Orgs.) Villes et régions au Brésil. Paris: L’Harmatan, 2000. p. 165-191.

MADEIRA, W. V. Modelos de desenvolvimento econômico e ordenamento territorial na Amazônia: rupturas e continuidades no corredor Açailândia-São Luís (MA). 2015. 236 fls. Tese (Doutorado em Desenvolvimento Sustentável do Trópico Úmido) - Programa de Pós-Graduação em Desenvolvimento Sustentável do Trópico Úmido, Núcleo de Altos Estudos Amazônicos, Universidade Federal do Pará, Belém, 2015.

MELlO, N. A. Políticas territoriais na Amazônia. São Paulo: Annablume, 2006. 412 p.

MONTE-MOR, R. L. M. Urbanização e modernização na Amazônia contemporânea. In: LIMONAD, E.; HAESBAERT, R.; MOREIRA, R. (Orgs.). Brasil, século XXI: por uma nova regionalização? Agentes, processos e escalas. São Paulo: Max Limonad, 2004. p. 112-122.

MONTE-MOR, R. L. M. Extended urbanization and settlement patterns in Brazil: an environmental approach. In: BRENNER, N. (Ed.). Implosions/explosions: towards a study of planetary urbanization. Berlin: Jovis, 2014a, p. 109-120.

MONTE-MOR, R. L. M. What is the urban in the contemporary world?. In: BRENNER, N. (Ed.). Implosions/explosions: towards a study of planetary urbanization. Berlin: Jovis, 2014b, p. 260-267.

OLIVEIRA, J. A. Cidades na selva. Manaus: Valer, 2000. 224p.

PORTO-GONÇALVES, C. W. Amazônia, amazônias. São Paulo: Contexto, 2001. 178 p.

SATHLER, D; MONTE-MÓR, R. L.; CARVALHO, J. A. M. As redes para além dos rios: urbanização e desequilíbrio na Amazônia brasileira. Nova Economia, Belo Horizonte, v. 19, n. 1, p. 11-39, jan.-abr. 2009. SANTOS, M. A urbanização brasileira. São Paulo: Hucitec, 1993. 157 p.

SIMONI SANTOS, C. R. A nova centralidade da metrópole: da urbanização expandida à acumulação especificamente urbana. 2013. 307 fls. Tese (Doutorado em Geografia Humana) - Departamento de Geografia, Faculdade de Filosofia, Letras e Ciências Humanas, Universidade de São Paulo, São Paulo, 2013.

SOJA, E. Para além de postmetropolis. Revista UFMG, Belo Horizonte, v. 20, n.1, p.136-167, jan./jun. 2013. SOJA, E. Regional urbanization and the end of metropolis era. In: BRENNER, N. (Ed.). Implosions/explosions: towards a study of planetary urbanization. Berlin: Jovis, 2014. p. 276-287.

SPOSITO, M. E. B. As cidades médias e os contextos econômicos contemporâneos. In: (Org.) Urbanização e cidades: perspectivas geográficas. São Paulo: UNESP, 2001a. p. 609-643.

SPOSITO, M. E. B. Novas formas comerciais e redefinição da centralidade intra-urbana. In: (Org.). Textos e contextos para a leitura geográfica de uma cidade média. Presidente Prudente: GAsPEER/ UNESP, 2001b. p. 235-253.

SOUZA, E. A. de. Políticas públicas e práticas discursivas do desenvolvimento territorial na Amazônia: uma análise do Programa Territórios da Cidadania no Nordeste Paraense. 2014. 286 fls. Tese (Doutorado em Desenvolvimento Sustentável do Trópico Úmido) - Programa de Pós-Graduação em Desenvolvimento Sustentável do Trópico Úmido, Núcleo de Altos Estudos Amazônicos, Universidade Federal do Pará, Belém, 2014. TRINDADE JR., S-C. C. A cidade dispersa: os novos espaços de assentamentos em Belém e a reestruturação metropolitana. 1998. 395 fls. Tese (Doutorado em Geografia Humana) - Departamento de Geografia, Faculdade de Filosofia, Letras e Ciências Humanas, São Paulo, 1998. 
TRINDADE JR., S-C. C. Diferenciação territorial e urbanodiversidade: elementos para pensar uma agenda urbana em nível nacional. Cidades, Presidente Prudente, Grupo de Estudos Urbanos, v. 7, n. 12, p. 227-255, jul.-dez. 2010.

TRINDADE JR., S-C. C. Das "cidades na floresta" às "cidades da floresta": espaço, ambiente e urbanodiversidade na Amazônia brasileira. Papers do NAEA, Belém, n. 321, p. 1-22, dez. 2013.

TRINDADE JR., S-C. C.; RIBEIRO, R. Marabá: novos agentes econômicos e novas centralidades urbano-regionais no sudeste paraense. In: TRINDADE JR., S-C C. et alii (Orgs.). Pequenas e médias cidades na Amazônia. Belém: ICSA/UFPA, 2009. p. 333-359.

Submitted december 2015

Accepted january 2016 